\title{
VARIETAL RESPONSE OF MAIZE (ZEA MAYS L.) AGAINST WEEDS AQUEOUS EXTRACTS
}

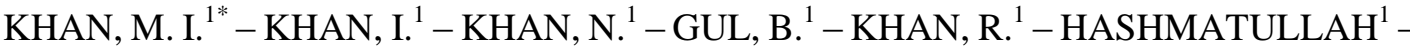 \\ AHMAD, I. ${ }^{1}-$ KHAN, I. A. ${ }^{1}-$ IQBAL, M. $^{3}-$ BIBI, ${ }^{2}{ }^{2}$ \\ ${ }^{1}$ Department of Weed Science, the University of Agriculture, Peshawar, Pakistan \\ ${ }^{2}$ Department of Soil and Environmental Sciences, the University of Agriculture, Peshawar, \\ Pakistan \\ ${ }^{3}$ Department of Agricultural Chemistry, the University of Agriculture, Peshawar, Pakistan \\ *Corresponding author \\ e-mail:mishfaq@aup.edu.pk \\ (Received $1^{\text {st }}$ Aug 2016; accepted $20^{\text {th }}$ Sep 2016)
}

\begin{abstract}
Allelopathic effects of the four weed species viz., Sorghum halepense L., Trianthema portulacastrum L., Parthenium hysterophorus L. and Xanthium strumarium L. were examined on maize (Zea mays L.) cultivars (Azam and Jalal) under greenhouse experiment. The experiment was arranged in completely randomized design (CRD) with factorial arrangements with three replications. The results indicated that the extracts of all the tested weeds had significantly affected all the studied parameters in maize cultivars as compared to the control treatment. However, among the weed extracts $T$. portulacastrum proved more suppressive to maize cultivars by producing the minimum plant height. Though, the effects of $S$. halepense and $P$. hysterophorus were also statistically comparable in some parameters with the effects of $T$. portulacastrum. On the other hand the varietal response towards weed extracts was found to be non-significant for all the studied parameters. It is concluded that the studied weeds should be exploited for their possible allelopathic affects for weed control in maize.
\end{abstract}

Keywords: weeds, allelopathy, maize cultivars, weeds extract, chemical ecology

\section{Introduction}

Maize (Zea mays L.) is one of the most important crop grown throughout the world both in rainfed and irrigated areas. It is used as food, fodder and also utilized as a raw material in industries. (Nazir et al., 1994). Weeds compete with crops through releasing toxic chemicals inhibit the growth of crop plant and interfere with them for available resources. The direct or indirect effect of one plant on another plant through release of chemicals is termed as "allelopathy" (Rice, 1984) or any process involving secondary metabolites produced by plants, algae, bacteria and fungi that influences the growth and development of agriculture and biological systems (International Allelopathy Society, IAS). The chemicals are referred as allelochemicals. Allelochemicals found in different plants are escaped into the environment through volatilization, leaching, exudation, and decomposition. Trianthema portulacastrum is one of the troublesome weed of maize crop in Pakistan (Saeed et al., 2011). This weed not only occupies space in maize field and share the available resources with maize but also release allelochemicals that reduce maize 34 plant height, leaf area, crop growth rate and crop biomass (Randhawa, 2009). $T$. portulacastrum also effect the growth of legumes due to the release of allelochemicals (Gricher, 2008). Mostly weeds are found to be harmful in different cultivated crops which cause losses in crops yield through various ways like competition and allelopathy in maize and wheat (Bhatt et al., 1994). The production of 
different crops greatly affected by the allelopathic effect of weeds and results in financial and yield losses (Alam, 1991). Among the grasses Sorghum halepense is famous for its high allelopathic potential. Different phenolic compounds are reported in different species of johnsongrass. (Duke et al., 2000). Parthenium hysterophorus is spreading rapidly throughout Pakistan and has become serious weed in many areas of Pakistan (Javaid and Anjam, 2006). P. hysterophorus inhibit the seed germination and seedling growth of many crops e.g. barley (Hordeum volgare L.) and maize (Rashid et al., 2008). It can reduce the carrying capacity of pastures by $90 \%$ (Rezene et al., 2005) as well as reduce biodiversity of these pastures and suppress the native flora of many countries (Frew et al., 1996). Parthenium weed has also been reported to be decreased the native flora of Pakistan (Shabbir and Bajwa, 2006). P. hysterophorus was introduced to Pakistan about ten years ago in the capital. Initially it was spread across road sides and railways track. Now days this weed specific weed spice dominated the whole country and appear as an epidemic in various crops especially the vegetable. $T$. portulacastrum, $S$. halepense and $X$. stromarium are also the main problem in maize crop, creating infestation on various growth stages of the maize crops in Pakistan. It is evident that $X$. stromarium was introduced back in 1980s when the Afghan refugees entered to Peshawar- Pakistan after Russian encounter on Afghanistan. Peshawar is the closest entrance from Afghanistan to Pakistan. As X. stromarium seeds having stings and they attached with fur and wool of cattle. This was the main reason of the infestation of $X$. stromarium in Peshawar Pakistan. Keeping in view the importance of such studies a research trial was conducted to evaluate the allelopathic prospective of weeds on maize cultivars and to find out the capability of tolerance of maize cultivars against the allelopathic weeds extracts.

\section{Materials and Methods}

In summer, 2015 a pot experiment was conducted at the Weed Science Department, The University of Agriculture, Peshawar, Pakistan to find out the allelopathic potential of four common weeds of maize crop viz. Sorghum halepense, Trianthema portulacastrum, Parthenium hysterophorus and Xanthium strumarium were examined against two common and widely cultivated maize cultivars i.e. "Azam" and "Jalal". The Peshawar is situated near the eastern end of the Khyber Pass and sits mainly on the Iranian plateau along with the rest of the Khyber-Pakhtunkhwa. Peshawar is literally a frontier city of South-Central Asia and was historically part of the Silk Road. Winter in Peshawar starts from mid-November to the end of March. Summer months are May to September. The mean maximum temperature in summer is over $40{ }^{\circ} \mathrm{C}\left(104^{\circ} \mathrm{F}\right)$ and the mean minimum temperature is $25^{\circ} \mathrm{C}\left(77^{\circ} \mathrm{F}\right)$. The mean minimum temperature during winter is $4{ }^{\circ} \mathrm{C}\left(39^{\circ} \mathrm{F}\right)$ and maximum is $18.35^{\circ} \mathrm{C}\left(65.03{ }^{\circ} \mathrm{F}\right)$.

Peshawar is not situated in the monsoon region, unlike the other northern parts of Pakistan. But occasionally monsoon currents make it as far as Peshawar causing downpours. This can be witnessed in the erratic monsoon of 2015 when the monsoon moisture was going well into eastern Afghanistan. The winter rainfall due to western disturbances shows a higher record during the months of February and April. The highest winter rainfall has been recorded in March, while the highest summer rainfall in the month of August. The average winter rainfall is higher than that of the summer. Based on a 30-year record, the average 30-year annual precipitation has been recorded 
as 400 millimetres (16 in). The relative humidity varies from $46 \%$ in June to $76 \%$ in August (Wikipedia).

\section{Weeds Collection}

The above mentioned weeds were collected at mature stage from the New Developmental Farm, The University of Agriculture Peshawar, Pakistan and were identified in the herbarium of Weeds Science Department, The University of Agriculture, Peshawar, Pakistan.

\section{Extract Preparation}

The collected weed samples were washed and chopped into small pieces and packed in paper bags. Then samples were kept in the oven at $65{ }^{\circ} \mathrm{C}$ for 48 hours in order to remove the moisture content. The dried samples were then subjected to a mechanical grinder in order to receive fine powder for the water extract preparation. The samples were then soaked in distilled water at $120 \mathrm{~g} \mathrm{~L}^{-1}$ for 24 hours in separate containers to get aqueous extract from all the collected weed samples. The obtained extracts were filtered from muslin cloth to obtain aqueous allelopathic extracts solution.

\section{Experimental Design}

The experiment was arranged in Completely Randomized Design with factorial arrangement having three replications. Following are the two factors studied in the trial i.e. factor A (maize cultivars) viz. Azam and Jalal and factor B (weed extracts) viz. Sorghum halepense, Trianthema portulacastrum, Parthenium hysterophorus and Xanthium strumarium.

\section{Experimental Setup}

First of all the desired pots having the size of $12 \times 15 \mathrm{~cm}$ were filled with weed seed free soil. Ten seeds of each maize variety were sown in assigned pots which mean thirty specimens were studied against each weed extracts. When the maize seeds were germinated the prepared weed extract were applied in a single dose $\left(120 \mathrm{~g} \mathrm{~L}^{-1}\right)$ to each assigned pots. A separate treatment of distilled water was also kept for the comparison. The total duration of the instant trial was 40 days. Almost data were recorded when all the studied plants got seedling stage. Moreover, data were recorded on the following parameters with subsequent procedure.

\section{Plant height (cm)}

The plant height was measured with a ruler in $\mathrm{cm}$, for all the plants in each individual pot treated with respective weed extracts and then averaged.

\section{Fresh shoot biomass (g)}

The fresh biomass of all maize plants collected from each pot was taken on an electric balance and the means plant $^{-1}$ were calculated for each treatment.

\section{Dry shoot biomass $(g)$}

Already collected fresh plants were kept in oven for 24 hours at $65{ }^{\circ} \mathrm{C}$ after drying the data was recorded for dry biomass and averaged. 


\section{Leaf area $\left(\mathrm{cm}^{2}\right)$}

The leaf area of all the leaves in a single pot was measured through leaf area meter and the mean was recorded finally for calculating leaf area for a single leaf.

\section{Statistics}

The data recorded were analyzed statistically through MSTATC and least significant difference (LSD) were calculated by the procedure stated by Steel et al., 1997.

\section{Results}

\section{Plant Height (cm)}

The results presented in (Table 1) revealed that both maize cultivars showed nonsignificant response to the treatments (weed extracts). However, maximum plant height $(37.94 \mathrm{~cm})$ was observed for Jalal variety and the minimum plant height $(36.29 \mathrm{~cm})$ was noted for "Azam" variety. On the other hand, the treatments (weed extracts) revealed significant inhibitory effects on the plant height of maize cultivars. The maximum plant height $(42.80 \mathrm{~cm})$ was computed for the control treatment and the minimum plant height $(33.85 \mathrm{~cm})$ was recorded in Trianthema portulacastrum extract, followed by Parthenium hysterophorus extract $(34.46 \mathrm{~cm})$. The interaction among the treatments and maize cultivars also showed significant variation in data for plant height. The maximum plant height $(44.53 \mathrm{~cm})$ was recorded in control x "Jalal" variety, while the minimum plant height $(33.10 \mathrm{~cm})$ was recorded in $P$. hysterophorus extract x "Jalal" variety. (Khan et al., 2012) found that aqueous extracts of $P$. hysterophorus L. had significant inhibitory effects on the seedling elongation and germination. It is evident from the results that there were no statistically significant difference between the tested cultivar, while the weed extracts showed clear differences. So it is concluded that weed extracts having suppressive abilities should be exploited in future for the possible allelopathic compounds or secondary metabolites that should be used as a bioherbicides for weed control in maize.

Table 1. Plant height (cm) of maize cultivars as effected by different weed extracts.

\begin{tabular}{l|c|c|c}
\hline \multirow{2}{*}{ Weed extracts } & \multicolumn{2}{|c|}{ Maize cultivars } & \multirow{2}{*}{ Means } \\
\cline { 2 - 3 } & Azam & Jalal & \\
\hline Trianthema portulacastrum & $33.36 \mathrm{~d}$ & $34.33 \mathrm{~cd}$ & $33.85 \mathrm{c}$ \\
Parthenium hysterophorus & $35.83 \mathrm{bcd}$ & $33.10 \mathrm{~d}$ & $34.46 \mathrm{c}$ \\
Xanthium strumarium & $37.93 \mathrm{bcd}$ & $39.46 \mathrm{abc}$ & $38.70 \mathrm{~b}$ \\
Sorghum halepense & $33.25 \mathrm{~d}$ & $38.26 \mathrm{bcd}$ & $35.76 \mathrm{bc}$ \\
Control & $41.06 \mathrm{ab}$ & $44.53 \mathrm{a}$ & $42.80 \mathrm{a}$ \\
\hline Cultivars Means & 36.29 & 37.94 & \\
\hline
\end{tabular}

Lsd (0.05) for weed extracts $=4.06$

Lsd $(0.05$ for maize cultivars $=$ NS

Lsd (0.05) for Interaction $=5.74$ 


\section{Fresh biomass (g)}

The (Table 2) showed non-significant results for cultivars means regarding the fresh biomass. However, numerically the outmost fresh biomass $(27.18 \mathrm{~g})$ was recorded for "Jalal" variety and the minimum fresh biomass (26.42 g) was noticed in "Azam" variety. Although the weed extracts mean showed significant results. The maximum fresh biomass ( $32.48 \mathrm{~g}$ ) was recorded in the control treatment and the minimum fresh biomass $(24.18 \mathrm{~g})$ was observed under the application of Trianthema portulacastrum extract. The interaction of treatments and maize cultivars also showed significant results. The maximum fresh biomass $(33.16 \mathrm{~g})$ was recorded in control x "Jalal" variety, while the minimum fresh biomass $(23.80 \mathrm{~g})$ was recorded in $T$. portulacastrum extract x "Azam" variety.

Table 2. Fresh biomass ( $g$ ) of maize cultivars as affected by different weed extracts.

\begin{tabular}{l|c|c|c}
\hline \multirow{2}{*}{ Weed extracts } & \multicolumn{2}{|c|}{ Maize cultivars } & \multirow{2}{*}{ Means } \\
\cline { 2 - 3 } & Azam & Jalal & \\
\hline Trianthema portulacastrum & $23.80 \mathrm{c}$ & $24.56 \mathrm{bc}$ & $24.18 \mathrm{c}$ \\
Parthenium hysterophorus & $27.40 \mathrm{~b}$ & $25.43 \mathrm{bc}$ & $26.41 \mathrm{~b}$ \\
Xanthium strumarium & $24.63 \mathrm{bc}$ & $27.26 \mathrm{~b}$ & $25.95 \mathrm{bc}$ \\
Sorghum halepense & $24.46 \mathrm{bc}$ & $25.46 \mathrm{bc}$ & $24.96 \mathrm{bc}$ \\
Control & $31.80 \mathrm{a}$ & $33.16 \mathrm{a}$ & $32.48 \mathrm{a}$ \\
Cultivars Means & 26.42 & 27.18 & \\
\hline
\end{tabular}

Lsd (0.05) for weed extracts $=2.11$

Lsd $(0.05$ for maize cultivars $=\mathrm{NS}$

Lsd (0.05) for Interaction $=2.99$

\section{Dry biomass (g)}

Like the fresh biomass the present parameters were also found non-significant for maize cultivars (Table 3). The numerical data for cultivars means indicated that maximum dry biomass (9.68 g) was observed for the "Azam" variety and the minimum dry biomass $(9.53 \mathrm{~g})$ was recorded for "Jalal" variety. However, all the treatment had showed significant inhibitory effects on the maize cultivars. The maximum dry biomass (10.35 g) was recorded in the control treatment and the minimum dry biomass $(9.11 \mathrm{~g})$ was noticed in Trianthema portulacastrum extract, although it was statistically comparable with Sorghum halepense, Parthenium hysterophorus and Xanthium strumarium. Khan et al. (2012) also reported that $T$. portulacastrum having allelopathic potential against the maize crop. The data shows that $S$. halepense, $T$. portulacastrum, $P$. hysterophorus and X. strumarium has strong allelopathc potential against the dry biomass of maize cultivars. The interaction among the treatments and maize cultivars are also significantly affected as shown in table-3. The maximum dry biomass $(10.40 \mathrm{~g})$ was recorded in control x "Jalal" variety, while the minimum dry biomass $(8.63 \mathrm{~g})$ was recorded in $T$. portulacastrum extract x "Azam" variety. 
Table 3. Dry biomass ( $g$ ) of maize cultivars as affected by different weed extracts.

\begin{tabular}{l|c|c|c}
\hline \multirow{2}{*}{ Weed extracts } & \multicolumn{2}{|c|}{ Maize cultivars } & \multirow{2}{*}{ Means } \\
\cline { 2 - 3 } & Azam & Jalal & \\
\hline Trianthema portulacastrum & $8.63 \mathrm{~d}$ & $9.60 \mathrm{abcd}$ & $9.11 \mathrm{~b}$ \\
Parthenium hysterophorus & $9.93 \mathrm{abc}$ & $9.00 \mathrm{~cd}$ & $9.46 \mathrm{~b}$ \\
Xanthium strumarium & $9.73 \mathrm{abc}$ & $9.40 \mathrm{abcd}$ & $9.56 \mathrm{~b}$ \\
Sorghum halepense & $9.80 \mathrm{abc}$ & $9.26 \mathrm{bcd}$ & $9.53 \mathrm{~b}$ \\
Control & $10.31 \mathrm{ab}$ & $10.40 \mathrm{a}$ & $10.35 \mathrm{a}$ \\
Cultivars Means & 9.68 & 9.53 & \\
\hline
\end{tabular}

Lsd (0.05) for weed extracts $=0.76$

Lsd $(0.05$ for maize cultivars $=\mathrm{NS}$

Lsd (0.05) for Interaction $=1.07$

\section{Leaf Area $\left(\mathrm{cm}^{2}\right)$}

The statistical analysis of the data showed non-significant variation between the means of both maize cultivars for leaf area. Although numerically the maximum leaf area $\left(25.42 \mathrm{~cm}^{2}\right)$ was recorded for maize variety "Azam" and the minimum leaf area $\left(24.66 \mathrm{~cm}^{-2}\right)$ was recorded for "Jalal" variety (Table 4). Among the weed extracts the maximum leaf area $\left(32.83 \mathrm{~cm}^{2}\right)$ was noted for the control treatment, while minimum leaf area $\left(21.55 \mathrm{~cm}^{2}\right)$ was observed in Sorghum halepense treated pots that are statistically at par with other weed extracts like Trianthema portulacastrum, Parthenium hysterophorus and Xanthium strumarium. Furthermore, the interaction between the treatments (weed extracts) and cultivars in (Table 4) showed that the maximum leaf area $\left(35.66 \mathrm{~cm}^{2}\right)$ was noticed in control x "Jalal" variety and minimum leaf area $\left(21.13 \mathrm{~cm}^{2}\right)$ was recorded for $S$. halepense extract x "Jalal” variety.

Table 4. Leaf area $\left(\mathrm{cm}^{-2}\right)$ of maize cultivars as affected by different weed extracts.

\begin{tabular}{l|c|c|c}
\hline \multirow{2}{*}{ Weed extracts } & \multicolumn{2}{|c|}{ Maize cultivars } & \multirow{2}{*}{ Means } \\
\hline Trianthema portulacastrum & $27.40 \mathrm{~b}$ & $22.26 \mathrm{~b}$ & $24.83 \mathrm{~b}$ \\
Parthenium hysterophorus & $24.96 \mathrm{~b}$ & $22.36 \mathrm{~b}$ & $23.66 \mathrm{~b}$ \\
Xanthium strumarium & $22.76 \mathrm{~b}$ & $21.86 \mathrm{~b}$ & $22.31 \mathrm{~b}$ \\
Sorghum halepense & $21.96 \mathrm{~b}$ & $21.13 \mathrm{~b}$ & $21.55 \mathrm{~b}$ \\
Control & $30.00 \mathrm{ab}$ & $35.66 \mathrm{a}$ & $32.83 \mathrm{a}$ \\
Cultivars Means & 25.42 & 24.66 & \\
\hline
\end{tabular}

Lsd (0.05) for weed extracts $=7.08$

Lsd $(0.05$ for maize cultivars $=\mathrm{NS}$

Lsd (0.05) for Interaction $=10.01$ 


\section{Discussions}

The data in (Table 1) shows that $T$. portulacastrum, $P$. hysterophorus, $S$. halepense and $X$. strumarium possess highly allelopathic chemicals which have the ability to reduce the plant height of maize cultivars. Hence, it is concluded that the allelochemicals found in S. halepense and P. Hysterophorus disturbed the normal functioning in maize plants that leads to the retardation of maize plant height. Similarly, Jabeen and Ahamd (2009) also found inhibitory effects of different weeds extract on plant height of maize cultivars. Kumar and Kumar (2010) also declared parthenium weed as the worst invasive weeds which effect the summer crops plant through its allelopathy and adversely affect the biodiversity.

The results regarding (Table-2) shows the $T$. portulacastrum contains allele chemicals which retard the growth and reduce the fresh biomass of the maize crop. $T$. portulacastrum spread in the fields very effectively and has the quality of prolific seed production due to which it affects the crop normal functioning (Duke et al., 2000). Moreover, this weed contains several phenolic compounds responsible for growth retardation in maize crop (Saeed et al., 2010).

The above results in (Table 3) are found similar with those of (Mubeen et al. 2011) who stated that $T$. portulacastrum contains allelochemicals which contribute to the reduction in the dry biomass of maize crop. (Khan et al., 2011) also found similar results in his experiment on examination the effect of $S$. halepense, $T$. portulacastrum, $P$. hysterophorus on the seed germination of wheat crop.

Hence, it is concluded from the results in Table 3 that the allelochemicals found in $S$. halepense had significant inhibitory effects on the growth of maize cultivars as a result the leaf elongation in maize cultivars has disturbed. In other studies (Singh et al. 2005) also noted the reduction in root and shoot lengths of 40-47\% over the control in other species on exposing to $S$. halepense extracts.

\section{Conclusion and Recommendations}

On the basis of this trail it may be concluded that the weeds: Trianthema portulacastrum and Sorghum halepense aqueous extract contain allelochemicals that negatively affected the growth of maize cultivars. Therefore, the proper control of these weeds is suggested in maize crop to avoid the losses. Moreover, the phytotoxic properties of these weeds can be utilized as a tool for controlling weed in summer crops after laboratory tests.

\section{REFERENCES}

[1] Alam, S. M. (1991): Weed Science Problem in Pakistan. - Pak Gulf Eco 3-9: 25-29.

[2] Bhatt, H. G., Chauhan, D. S., Todaria N.P. (1994): Effect of weed leachates on germination and radical extension of some food crops. - Indian Journal Plant Phys 37:177-179.

[3] Bajwa, A. A. (2014): Sustainable weed management in conservation agriculture. - J Crop Prot 65: 105-113.

[4] Gricher. (2008): Horse purselane Trianthema portulacastrum control in peanut (Arachishypogaea). - Weed Techechnology 7: 570-572.

[5] Duke, S.O., Dayan, F.E., Romagni, J.G., Rimando. A.M. (2000): Natural products as sources of herbicides: current status and future trends. - Weed Research 40: 99-111. 
[6] Frew, M., Solomon, K., Mashilla, D. (1996): Prevalence and distribution of Parthenium hysterophorus L. in eastern Ethiopia. - Arem 1: 19-26.

[7] Khan, I., Ali, Z. Khan, M.I., Hussain, Z. Khan, I.A., Waqas, M., Khan, R., Khan, S. (2014): Allelopathic effects of some weeds on chickpea crop. - Pakistan Journal of Weed Science Res 20(2): 207-211.

[8] Khan, M.A., Kalsoom, U. Khan, M.I., Khan, R. Khan, S.A. (2011). Screening the allelopathic potential of various weeds. - Pakistan Journal of Weed Science Res 17(1): 73-81.

[9] Khan, N., Hashmatullah. Naveed, K. Hussain, Z. Khan, S.A. (2012): Assessment of allelopathic effects of Parthenium Parthenium hysterophorus L. plant parts on seed germination and seedling growth of wheat Triticum aestivum L. cultivars. - Pakistan Journal of Weed Science Res 18(1): 39-50.

[10] Jabeen, N. Ahamd, M. (2009): Possible Allelopathic effects of three different weeds on germination and growth of maize cultivars. - Pakistan Journal of Botany 41(4): 16771683.

[11] Javaid, A., Anjum, T. (2006): Control of Parthenium hysterophorus L. by aqueous extracts of allelopathic grasses. - Pakistan Journal of Botany 38: 139-145.

[12] Khan, B. M., Ahmad, M. Hussain, M. Jabran, K. Farooq, S. Waqas-ul-Haq M. (2012): Allelopathic plant water extracts tank mixed with reduced doses of atrazine efficiently control Trianthema portulacastrum L. in Zea mays L. - Journal of Animal and Plant Science 22(2): 339-346.

[13] Kumar, M., Kumar, S. (2010): Effect of Parthenium hysterophorus L. ash on growth and biomass of Phaseolus mungo L. - Academia Arena 2: 98-102.

[14] Mubeen, K., Nadeem, M. A., Tanveer, A. Zahir, Z. A. (2011): Allelopathic effect of aqueous extracts of weeds on the germination and seedling growth of rice Oryza sativa L. - Pakistan Journal of Life Social Science 9(1): 87-92.

[15] Rezene, F., Chichayibelu. M, Giorgi, M.H. (2005): Spread and ecological consequences of Parthenium hysterophorus L. - Ethiopia Arem 6: 11-21.

[16] Rice, E. L. (1984): Allelopathy. 2nd Ed. - Academic Press. New York, U.S.A.

[17] Rashid, H., Khan, M. A., Amin, A., Nawab, K., Hussain, N., Bhowmik, P. K. (2008): Effect of Parthenium hysterophorus L. root extracts on seed germination and growth of maize and barley. - American Journal of Plant Science Biotechnology 2 (2): 51-55.

[18] Randhawa, M. A., Khan, M. A.J., Khan, N.H., Asif, M. (2009): Influence of Trianthema portulacastrum infestation and plant spacing on the yield and quality of maize grain. International Journal of Agriculture Biology 11(2): 225-227.

[19] Nazir, S., Bashir, E., Bantel, R. (1994): Crop Production. - National Book Foundation, Islamabad.

[20] Shabbir, A., Bajwa, R. (2006): Distribution of parthenium weed Parthenium hysterophorus L., an alien invasive weed species threatening the biodiversity of Islamabad. - Weed Biology and Managment 6: 89-95

[21] Singh, H.P., Batish, D.R., Pandher, J.K., Kohil, R.K. (2005): Phytotoxic effects of Parthenium hysterophorus residues on three Brassica species. - Weed Biology and Managment 5(3): 105-109

[22] Saeed, M., Marwat, K. B., Hassan, G., Khan, A., Khan, I.A. (2010): Interference of horse purslane Trianthema portulacastrum L. with maize Zea mays L. at different densities. - Pakistan Journal of Botany 42(1): 173-179.

[23] Saeed, M., Ashfaq, M., Gul, B. (2011): Effect of different allelochemicals on germination and growth of horse purslane. - Pakistan Journal of Botany 43(4): 21132114.

[24] Steel, R.G.D., Torrie, J.H., Dicky, D. (1997): Principles and Procedures of Statistics. Multiple comparison. 3rd Ed. - Mc Graw Hill Book Co., New York, USA. pp. 178-198. 